CZU 343.3

https://doi.org/10.52507/2345-1106.2021-1.12

\title{
CONFISCAREA EXTINSĂ
}

ZLATE Nadia,

Procuror DNA- Structura Teritorială Constanța, Doctorand, Institutul de Cercetări Juridice „, Academician Andrei Rădulescu”

a Academiei Române

Email: zlate_nadia@yahoo.com

\section{REZUMAT}

Confiscarea extinsă este măsura de siguranţă are caracter personal ce constă în trecerea silită și gratuită în patrimoniul statului a unor bunuri, în cazurile și în condiţiile prevăzute de lege, care se poate dispune în cazul condamnării unei persoane pentru comiterea unei infracțiuni de o anumită gravitate susceptibilă de a procura un folos material, atunci când instanța își formează convingerea că bunurile respective provin din activități infracționale.

Convingerea instanţei trebuie să fie deplină, în baza circumstanţelor cauzei, a unor fapte specifice, cu privire la faptul că bunurile respective sunt rezultatul unor activităţi infracţionale desfãșurate de persoana condamnată. Probele administrate nu trebuie să fie apte să conducă la condamnarea inculpatului și pentru aceste activităţi infracţionale , ci e suficient să fie de natura a crea instanţei convingerea că bunurile provin din activităţi infracţionale.

Îndeplinesc această condiţie și bunurile dobândite de persoana condamnată în această perioadă, dar care nu se mai găsesc în posesia sau în proprietatea sa, fiind transferate către terţe persoane, dacă aceștia ştiau sau ar fi trebuit să știe [1] că scopul transferului era evitarea confiscării.

Cuvinte-cheie: măsuri de siguranţă, confiscarea extinsă, standardul de probă, lege penală mai favorabilă.

\section{EXTENDED CONFISCATION}

ZLATE Nadia,

Prosecutor NAD - Constanța Territorial Structure, PhD student, Legal Research Institute „Acad. Andrei Rădulescu” of Romanian Academy Email: zlate_nadia@yahoo.com

\section{SUMMARY}

Extended confiscation is a personal security measure consisting in the forced and gratuitous transfer of property to the state patrimony, in the cases and under the conditions provided by law, which may be ordered in case of conviction of a person for committing a crime of a certain susceptibility to procure a material benefit, when the court is convinced that the goods in question come from criminal activities.

The conviction of the court must be complete, based on the circumstances of the case, of specific facts, regarding the fact that the respective goods are the result of some criminal activities carried out by the convicted person. The evidence administered must not be capable of leading to the conviction of the defendant for these criminal activities as well, but it is sufficient to be such as to create in the court the conviction that the goods come from criminal activities.

The property acquired by the convicted person during this period, but which is no longer in his possession or property, being transferred to third parties, if they knew or should have known [1] that the purpose of the transfer was to avoid confiscation, also fulfill this condition. .

Key words: security measures, extended confiscation, standard of proof, more favorable criminal law. 
Noțiunea de confiscare extinsă. Confiscarea extinsă este una din măsurile de siguranță reglementate de Codul penal, alături de obligarea la tratament medical, internarea medicală, interzicerea ocupării unei funcţii sau a exercitării unei profesii și confiscarea extinsă.

Măsurile de siguranţă sunt sancţiuni de drept penal menite să lărgească gama de sancţiuni necesare prevenirii fenomenului infracţional.

Prin săvarşirea unei fapte prevăzute de legea penală se pun în evidenţă anumite împrejurări din realitatea socială, care sunt implicate în cauzalitatea acesteia şi care daca nu sunt combatute exista pericolul săvarşirii de noi fapte prevazute de legea penală, de ex.: starea de nepregatire profesională a făptuitorului care a comis infracţiuni din culpă datorita acestei nepregatiri poate constitui sursa unor noi fapte prevazute de legea penală [2].

Măsurile de siguranţă au în principal caracter preventiv, pentru că sunt destinate să preîntampine, prin înlaturarea stărilor de pericol, savarșirea de noi fapte prevăzute de legea penală, fie de către cel faţă de care sa luat măsura de siguranţă, fie chiar de alte persoane.

Măsurile de siguranţă au un caracter imprescriptibil, ele nu pot fi înlaturate prin trecerea timpului atta timp cat exista starea de pericol şi, deasemenea, sunt în principiu revocabile, cu exceptia confiscării speciale si a confiscării extinse.

Confiscarea extinsă este măsura de siguranţă are caracter personal ce constă în trecerea silită și gratuită în patrimoniul statului a unor bunuri, în cazurile și în condiţiile prevăzute de lege, care se poate dispune în cazul condamnării unei persoane pentru comiterea unei infracțiuni de o anumită gravitate susceptibilă de a procura un folos material, atunci când instanța își formează convingerea că bunurile respective provin din activități infracționale.

În anumite condiţii, confiscarea extinsă poate fi asimilată unei veritabile pedepse, așa cum a reținut Curtea Europeana a Drepturilor Omului (în continuare CEDO) în cauza Welch c. Regatului Unit al Marii

\section{${ }^{1}$ Potrivit art. $112^{1}$ din Codul penal:}

(1)Sunt supuse confiscării şi alte bunuri decât cele menţionate la art. 112, când față de o persoana se dispune condamnarea pentru o faptă susceptibilă să îi procure un folos material şi pentru care pedeapsa prevăzută de lege este închisoarea de 4 ani sau mai mare, instan ța $\hat{i}$ și formeaz ă convingerea c ă bunurile respective provin din activit $\breve{a}$ ţi infrac ţionale. Convingerea instan ţei se poate baza inclusive pe disproporţia dintre veniturile licite și averea persoanei.

2) Confiscarea extins ă se dispune asupra bunurilor dobândite de persoana condamnat ă într-o perioad ă de 5 ani înainte și,dac ă este cazul, dup ă momentul s ăv âr șirii infrac ţiunii, $p$ ân ă la data emiterii actului de sesizare a instan ţei. Confiscarea extins ă poate fi dispus ă și asupra bunurilor transferate c ăte terți, dacă aceștia știau sau ar fi trebuit s ă știe că scopul transferului a fost evitarea confiscării.

(3) Pentru aplicarea dispoziţiilor alin. (2) se va ţine seama şi de valoarea bunurilor transferate de către
Britanii [3] (par. 29-35). În cauză, CEDO a retinut ca pentru a atribui unei masuri luate de organele statului caracterul de pedeapsa este necesar a determina dacă măsura în cauză este impusă în urma unei condamnări pentru o infracțiune. Alte elemente care pot fi considerate relevante în acest sens sunt: natura și scopul măsurii în cauză, calificarea acesteia în dreptul intern, procedurile asociate adoptării și executării acesteia, precum şi gravitatea acesteia. In aceste conditii, trebuie ca masura sa respecte conditiile de proportionalitate ale unei sanctiuni penale in raport de scopul urmarit si sa nu se aplice ope legis [4].

În acest sens, în cauza Ismayilov c. Rusiei (par. 34), CEDO a reținut că trebuie verificat dacă a existat un raport de proporționalitate între confiscare, ca modalitate de asigurare a interesului general și protectia dreptului persoanei acuzate de a se folosi de bunurile sale, pentru ca acesteia sa nu ii fie impusa o sarcină excesivă.

Reglementarea confiscarii extinse. Instituția confiscării extinse a fost introdusă în legislația penală romană, ca măsură de siguranță, prin Legea 63/2012 [5], reglementare prin care s-a urmărit transpunerea DecizieiCadru 2005/212/JAI a Consiliului din 24 februarie 2005 privind confiscarea produselor, a instrumentelor și a bunurilor având legătură cu infracțiunea [6], introducându-se astfel, în art. 1182 din Codul penal din 1968 și în art. $112^{11}$ din Codul penal în vigoare.

Legea nr. 228/2020 [7] a modificat reglementarea existentă în România, iar din expunerea de motive [8] reiese că modificarea s-a impus ca urmare a apariţiei Directivei 2014/42/UE.

Spre deosebire de reglementarea anterioară, în prezent, se poate dispune confiscarea extinsă dacă o persoană este condamnată pentru comiterea oricărei infracţiuni sancţionate de lege cu închisoarea de 4 ani sau mai mare şi are bunuri dobândite în ultimii cinci ani despre care instanța este convinsă că provin din orice activităţi infracționale.

În ceea ce privește dreptul Uniunii Europene, măsura confiscării este reglementată într-un cadru general în Directiva 42/2014 privind îngheţarea şi confiscarea

persoana condamnată ori de un terţ unui membru al familiei sau unei persoane juridice asupra căreia persoana condamnată deţine controlul.

(4) Prin bunuri, conform prezentului articol, se înţelege şi sumele de bani.

(5) La stabilirea diferenţei dintre veniturile licite şi valoarea bunurilor dobândite se vor avea în vedere valoarea bunurilor la data dobândirii lor şi cheltuielile făcute de persoana condamnată, membrii familiei acesteia.

(6) Dacă bunurile supuse confiscării nu se găsesc, în locul lor se confiscă bani şi bunuri până la concurenţa valorii acestora.

(7) Se confiscă, de asemenea, bunurile şi banii obţinuţi din exploatarea sau folosirea bunurilor supuse confiscării, precum şi bunurile produse de acestea.

(8) Confiscarea nu poate depăşi valoarea bunurilor dobândite în perioada prevăzută la alin. (2), care excedează nivelului veniturilor licite ale persoanei condamnate. 
instrumentelor şi produselor infracţiunilor săvârşite în Uniunea Europeană [9], ce conţine dispoziţii atât cu privire la confiscarea specială, cât și la cea extinsă.

Alte reglementări generale în dreptul Uniunii Europene în ceea ce privește confiscarea extinsă sunt Decizia-cadru a Consiliului 783 din 06 octombrie 2006 privind aplicarea principiului recunoașterii reciproce pentru hotărârile de confiscare [10], Decizia-cadru 2003/577/JAI a Consiliului din 22 iulie 2003 privind executarea ordinelor de înghețare a bunurilor sau a probelor [11] și Regulamentul (UE) 2018/1805 al Parlamentului European și al Consiliului din 14 noiembrie 2018 privind recunoașterea reciprocă a ordinelor de indisponibilizare și de confiscare [12] .

Condiţii pentru dispunerea măsurii de siguranţa a confiscării extinse. Să fi fost comisă una sau mai multe infracţiuni pentru care pedeapsa prevăzută de lege este închisoarea de 4 ani sau mai mare.

Măsura confiscării extinse se poate dispune doar în cazul săvârșirii unei infracţiuni, iar nu și în cazul comiterii doar a unei fapte prevăzute de legea penală, ca în cazul celorlalte m ăsuri de siguranţă. Prin urmare, fapta comis ă trebuie să fie tipică, antijuridică și imputabilă.

Condiţia menţionată mai sus a fost modificată prin Legea 228/2020 în sensul ca s-a eliminat lista restritivă privind infracţiunile care puteau atrage masura confiscării extinse ${ }^{2}$ pentru o combatere mai eficientă a fenomenului infracţional. Astfel, va fi posibil ă confiscarea extinsă și pentru alte infracţiuni, cum ar fi cele de serviciu.

Instanţa să fi dispus condamnarea inculpatului pentru săvârșirea acelei infracţiuni susceptibile să îi procure un folos material.

Dispunerea unei soluţii de condamnare de instanţa de judecată este de esenţa confiscării extinse. Nu prezintă relevan ţa felul sau cuantumul pedepsei efectiv aplicate, put ând fi vorba de o pedeapsă cu amenda, cu închisoarea ( chiar suspendată sub supraveghere) sau detenţiunea pe viaţă.

În doctrină [13] s-a opinat că se poate dispune confiscarea extinsă chiar și ca urmare a aplicării unei măsuri educative pentru fapte comise în minorat. $\mathrm{Nu}$ împărtă șim această opinie având în vedere că normele privind sancţiunile de drept penal sunt imperative, de precursori;

2 a) infracţiuni privind traficul de droguri şi de

b) infracţiuni privind traficul şi exploatarea persoanelor vulnerabile;

României;

c) infracţiuni privind frontiera de stat a

d) infracţiunea de spălare a banilor;

e) infracţiuni din legislaţia privind prevenirea şi combaterea pornografiei; terorismului;

f) infracţiuni din legislaţia privind combaterea

g) constituirea unui grup infracţional organizat;

h) infracţiuni contra patrimoniului;

i) nerespectarea regimului armelor, muniţiilor, materialelor nucleare şi al materiilor explozive şi al precursorilor de explozivi restricţionaţi; strictă aplicare, astfel încât nu se poate extinde aria de aplicare a măsurii confiscării extinse în cazul comiterii unor infracţiuni pentru care nu se poate dispune condamnarea inculpaţilor, ci doar aplicarea unor măsuri educative potrivit art. 114 din Codul penal.

- Infracţiunea comisă să fie susceptibilă să îi procure infractorului un folos material.

Prin folos material se înţelege orice avantaj de natură patrimonială care ar fi putut fi obţinut de inculpat prin săvârșirea infracţiunii care i-a atras condamnarea. $\mathrm{Nu}$ este necesară obţinerea efectivă a folosului și nici chiar urmărirea obţinerii acestui folos de către inculpat (care poate acţiona în calitate de autor, instigator, complice).

-Instanţa să își formeze convingerea că bunurile respective provin din activităţi infracţionale.

Provenienţa ilicită a bunurilor se prezumă relativ, în baza disproporţiei dintre veniturile licite și bunurile deţinute, precum și din alte probe sau indicii temeinice ce rezultă din dosar.

Convingerea instanţei trebuie să fie deplină, în baza circumstanţelor cauzei, a unor fapte specifice, cu privire la faptul că bunurile respective sunt rezultatul unor activităţi infracţionale desfășurate de persoana condamnată. Probele administrate nu trebuie să fie apte să conducă la condamnarea inculpatului și pentru aceste activităţi infracţionale (caz în care bunurile ar fi supuse confiscării speciale), ci e suficient să fie de natura a crea instanţei convingerea că bunurile provin din activităţi infracţionale.

Referitor la standardele de probă în materia confiscării extinse, în considerentele Deciziei nr. 356/2014, instanța de contencios constituțional a reținut că: ,în contextul stabilirii faptului că prezumţia caracterului licit al dobândirii averii nu este o prezumţie absolută, caracterul relativ al acestei prezumţii nu determină o răsturnare a sarcinii probei, principiul actori incumbit probatio rămânând pe deplin aplicabil, (...). În doctrină, în privinţa sarcinii probei în materia confiscării, se arată că aceasta are trăsături specifice în sensul că se observă, pe de o parte, o ,relaxare” în ceea ce priveşte proba faptelor specifice sau a actelor de natura celor care au atras condamnarea, iar, pe de altă parte, o ,divizare” a sarcinii probei, cel în cauză având posibilitatea de a dovedi caracterul licit al bunurilor pe care le deţine.

valori;

j) falsificarea de monede, timbre sau de alte

k) divulgarea secretului economic, concurenţa neloială, nerespectarea dispoziţiilor privind operaţii de import sau export, deturnarea de fonduri, infracţiuni privind regimul importului şi al exportului, precum şi al introducerii şi scoaterii din ţară de deşeuri şi reziduuri;

1) infracţiuni privind jocurile de noroc;

m) infracţiuni de corupţie, infracţiunile asimilate acestora, precum şi infracţiunile împotriva intereselor financiare ale Uniunii Europene;

n) infracţiuni de evaziune fiscală;

o) infracţiuni privind regimul vamal;

p) infracţiuni de fraudă comise prin sisteme informatice şi mijloace de plată electronice;

q) traficul de organe, ţesuturi sau celule de origine umană. 
Curtea reţine, însă, că ,relaxarea” se referă doar la probarea faptelor sau a actelor de natura celor care au atras condamnarea, art. 1182 alin. 2 lit. b) din Codul penal din 1969 stabilind că instanţa trebuie să îşi formeze convingerea că bunurile respective provin din activităţi infracţionale, fără a fi nevoie de pronunţarea unei hotărâri de condamnare pentru aceste fapte, şi nicidecum că această „relaxare” se referă la dovedirea caracterului ilicit al bunurilor dobândite"”.

Activitătile infracţionale ale persoanei condamnate, din care trebuie să provină bunurile, pot fi de orice natură. Urmare a modificării legislative efectuate prin Legea 228/2020, nu mai este obligatoriu ca activităţile infracţionale (din care trebuie să provină bunurile persoanei condamnate) să fie de aceeași natură cu infracţiunea pentru care este acuzat inculpatul.

1. Obiectul confiscării extinse. Pot forma obiectul confiscării extinse bunuri ale persoanei condamnate care îndeplinesc următoarele condiţii:

- Bunurile au fost dobândite de persoana condamnată într-o perioadă de 5 ani înainte și, dacă e cazul, după momentul săvârșirii infracţiunii, $\mathrm{p}$ ân ă la data emiterii actului de sesizare a instanţei.

Se vor avea în vedere atât bunurile mobile, cât și bunurile imobile, sumele de bani și serviciile de care a beneficiat inculpatul. Perioada de 5 ani se va calcula regresiv, înapoi, plecând de la data comiterii infracţiunii.

Îndeplinesc această condiţie și bunurile dobândite de persoana condamnată în această perioadă, dar care nu se mai găsesc în posesia sau în proprietatea sa, fiind transferate către terțe persoane, dacă aceștia știau sau ar fi trebuit să știe [14] că scopul transferului era evitarea confiscării.

Curtea Constituțională, prin Decizia nr. 11 din 15 ianuarie 2015 [15] a admis excepţia de neconstituţionalitate ridicată direct de Avocatul Poporului şi a constatat că dispoziţiile art. 1121 alin. (2) lit. a) din Codul penal sunt constituționale în măsura în care confiscarea extinsă nu se aplică asupra bunurilor dobândite înainte de intrarea în vigoare a Legii nr. 63/2012 pentru modificarea şi completarea Codului penal al României și a Legii nr. 286/2009 privind Codul penal.

Curtea Constituțională a statuat că măsura confiscării extinse este o instituţie de drept material, astfel încât

3 În cauza Telbiș și Viziteu c. României, CEDO a arătat în Hotărârea din 26 iunie 2018 ( par. 68) că "a constatat în numeroase cauze anterioare că era legitim ca autorităţile interne competente să emită decizii de confiscare pe baza preponderenței probelor care sugerau că veniturile legale ale părților adverse nu erau suficiente pentru a achiziționa bunurile în cauză (a se vedea, de exemplu, Gogitidze și alții, citată anterior, pct. 107). Întradevăr, în cazul în care

o decizie de confiscare a fost rezultatul procedurii legate de produse provenind din infracțiuni grave, Curtea nu a solicitat probarea „dincolo de orice îndoială rezonabilă" a originii ilicite a bunurilor în cadrul unor astfel de proceduri. În schimb, probarea pe baza balanței probabilităților sau a probabilității ridicate a unei 66 norma criticată nu poate retroactiva cu privire la confiscarea bunurilor dobândite înainte de intrarea ei în vigoare, chiar dacă infracţiunile pentru care s-a dispus condamnarea sunt comise după această dată. S-a observat că, dacă s-ar dispune măsura confiscării extinse pentru bunurile dobândite înainte de intrarea în vigoare a Legii nr. 63/2012, s-ar încălca principiul neretroactivităţii legii consacrat de art. 15 alin. (2) din Constituţie ${ }^{4}$.

La stabilirea diferenţei dintre veniturile licite și valoarea bunurilor dobândite se vor avea în vedere valoarea bunurilor la data dobândiriilor și cheltuielile făcute de persoana condamnată și membrii de familie ai acesteia.

Dacă bunurile supuse confiscării nu se găsesc, în locul lor se confisc ă bani și bunuri până la concurenţa valorii acestora. Se confiscă, deasemenea, bunurile și banii obţinuţi din exploatarea sau folosirea bunurilor supuse confiscării, precum și bunurile produse de acestea.

- Bunurile supuse confiscării speciale să fie altele decât cele ce fac obiectul confiscării speciale, potrivit art. 112 din Codul penal ori decât cele care sunt restituite părţii civile.

5. Aspecte procedurale. În orice etapă a procesului penal se pot lua măsuri asigurătorii potrivit dispoziţiilor art. 249 din Codul de procedură penală asupra bunurilor supuse confiscarii extinse.

Masura confiscarii extinse se dispune de instanta de judecata odata cu solutionarea cauzei penale, ca urmare a condamnării inculpatului/inculpaţilor.

Pentru a se putea dispune confiscarea bunurilor aparţinând unor terţe persoane, acestea trebuie citate în procedurile judiciare pentru respectarea dreptului la proprietate privată protejat prin art. 44 din Constituţie. În acest sens, la art. 353 alin. din Codul de procedura penala se prevede ca instanţa poate să dispună citarea altor subiecţi procesuali atunci cand prezenţa acestora este necesară pentru soluţionarea cauzei. Deasemenea, la art. 366 din Codul de procedură penală este reglementat dreptul persoanelor ale căror bunuri sunt supuse confiscării de a fi reprezentate de avocat, de a formula cereri, ridica excepţii și pune concluzii cu privire la măsura confiscării.

Titlul V al părții speciale a Codului de procedură

origini ilicite, coroborată cu incapacitatea proprietarului de a proba contrariul, s-a constatat a fi suficientă în sensul criteriului proporționalității, în temeiul art. 1 din Protocolul nr. 1." (http://ier.gov.ro/wpcontent/uploads/cedo/Telbis-si-Viziteu-impotrivaRomaniei.pdf)

4 În același mod, prin Decizia nr. 356/2014, Curtea Constituțională a reținut că prevederile privind confiscarea extinsă din Codul penal anterior (1969),,sunt constituţionale, în măsura în care confiscarea extinsă nu se aplică asupra bunurilor dobândite înainte de intrarea în vigoare a Legii nr. 63/2012 pentru modificarea şi completarea Codului penal al României şi a Legii nr. 286/2009 privind Codul penal" 
penală, intitulat „Executarea hotărârilor penale“, reglementează, la cap. II „Punerea în executare a hotărârilor", iar punerea în executare a măsurilor de siguranță este prevazuta la art. 566-574 din Codul de procedură penală.

Executarea masurii confiscării extinse este reglementată la art. 574 din Codul de procedură penală.

Astfel, lucrurile confiscate se predau organelor in drept a le prelua sau valorifica potrivit legii. Conform dispozitiilor art. 348 din Legea 207/2015 privind Codulul de procedura fiscal [16] confiscările dispuse de instanțele de judecată se duc la îndeplinire de către Ministerul Finanțelor Publice, Ministerul Afacerilor Interne sau, după caz, de către alte autorități publice abilitate de lege, prin organele competente, stabilite prin ordin comun al conducătorilor instituțiilor în cauză, iar valorificarea se face de organele competente ale Ministerului Finanțelor Publice, sau de către alte autorități publice abilitate de lege, cu respectarea prevederilor legale în vigoare.

Prin Legea nr. 318 din 11 decembrie 2015 pentru înființarea, organizarea și funcționarea Agenției Naţionale de Administrare a Bunurilor Indisponibilizate și pentru modificarea şi completarea unor acte normative
[17] au fost conferite acestei agentii atributii in legatura cu bunurile confiscate.

Astfel, potrivit articolului 31 din Legea 318/2015, Agenția ține evidența hotărârilor și a încheierilor prin care s-a luat măsura de siguranţă a confiscării speciale sau a confiscării extinse dispuse de instanțele române, precum și a celor comunicate autorităților române de către instanțele străine. Judecătorul delegat cu executarea transmite Agenției o copie a hotărârii sau a încheierii prin care s-a luat măsura de siguranță a confiscării speciale sau a confiscării extinse.

Bunurile aflate în administrarea Agenției, confiscate în cadrul procesului penal, se predau organelor de valorificare.

In ceea ce priveste contestarea actelor de executare a masurii confiscarii speciale, aceasta se va face in conditiile legii civile, asa cum prevad dispozitiile art. 600 din Codul de procedura penala.

În vederea identificării bunurilor supuse confiscării extinse, este necesar a se efectua o investigație financiară amănunţită, așa zisa metodă a inventarului, stabilindu-se în acest mod stilul de viaţă al persoanelor investigate și profilul financiar ${ }^{5}$.

\section{Referințe bibliografice:}

1. Legea nr. 228 din 02 noiembrie 2020 pentru modificarea și completarea unor acte normative din domeniul penal în vederea transpunerii unor directive ale Uniunii Europene. MONITORUL OFICIAL al României, nr. 1019 din 2 noiembrie 2020.

2. Mitrache Constantin, Mitrache Cristian, Drept penal roman. Partea generala. Editia a VIII-a rev ăzut ă şi ad ăugit ă, Ed. Universul Juridic, Bucure ști, 2010, p. 215.

3. https://hudoc.echr.coe.int (Vizitat 23.01.2021).

4. Udroiu Mihail, Drept penal. Partea generala. Editia V, Ed. C. H. Beck, Bucuresti, 2018, p. 571.

5. Monitorul Oficial al României, nr. 258 din 19 aprilie 2012, Partea I.

6. Jurnalul Oficial al Uniunii Europene nr. 19 din 15 martie 2006.

7. Monitorul Oficial al României, nr. 1019 din 2 noiembrie 2020, Partea I.

8. http://www.cdep.ro/proiecte/2017/500/30/7/em677.pdf

9. Jurnalul Oficial al Uniunii Europene nr. 127 din 29 aprilie 2014.

10. Jurnalul Oficial al Uniunii Europene nr. 328 din 24 noiembrie 2006. Dispozitiile acesteia au fost transpuse in legislatia romaneasca atat prin Codul penal prin vigoare, cat si prin Legea nr. 302/2004 privind cooperarea judiciară internațională în materie penală, republicată în M. Of., Partea I, nr. 377 din 31 mai 2011, iar ulterior modificată şi completată prin Legea nr. 300/2013 pentru modificarea și completarea Legii nr. 302/2004 privind cooperarea juridică internațională în materie penală, publicată în M. Of., Partea I, nr. 772 din 11 decembrie 2013, art. 307- 327

11. Jurnalul Oficial al Uniunii Europene nr. 196 din 02 august 2003. Dispozitiile acesteia au fost transpuse in legislatia romaneasca atat prin Codul penal prin vigoare, cat si prin Legea nr. 302/2004 privind cooperarea judiciară internațională în materie penală, republicată în M. Of., Partea I, nr. 377 din 31 mai 2011, iar ulterior modificată și completată prin Legea nr. 300/2013 pentru modificarea și completarea Legii nr. 302/2004 privind cooperarea juridică internațională în materie penală, publicată în M. Of., Partea I, nr. 772 din 11 decembrie 2013.

12. Publicat in Jurnalul Oficial al Uniunii Europene nr. 303 din 28 noiembrie 2018.

13. Udroiu Mihail, Sinteze de Drept penal. Partea generala, Ed. C. H. Beck, Bucuresti, 2020, p.802.

14. Legea nr. 228 din 02 noiembrie 2020 pentru modificarea și completarea unor acte normative din domeniul penal în vederea transpunerii unor directive ale Uniunii Europene. MONITORUL OFICIAL al României, nr. 1019 din 2 noiembrie 2020.

15. Monitorul Oficial al României, nr. 102 din 9 februarie 2015, Partea I.

16. Monitorul Oficial al României, nr. 547 din 23 iulie 2015, Partea I.

17. Monitorul Oficial al României, nr. 961 din 24 decembrie 2015, Partea I.

5 "Procedura privind efectuarea invetigaţiilor financiare în cadrul DNA", elaborat în cadrul proiectului "Înfrăţirea capacităţii de pregătire profesională a procurorilor și judecătorilor în domeniul luptei împotriva corupţiei şi criminalităţii financiare asociate” 